\title{
Physical-chemical monitoring of the Linhares (ES) and São Mateus (ES) aquatic ecosystem after the breaking of the Fundão Dam, Mariana, Minas Gerais
}

On November 5, 2015, in Bento Rodrigues, a subdistrict $35 \mathrm{~km}$ away from Mariana city, Minas Gerais state, the Fundão dam disaster took place, spreading approximately 16.000 Olympic pools of mining waste over the district of Bento Rodrigues in only 11 minutes. This plume of environmental impact extended approximately $800 \mathrm{~km}$ in the River Doce basin between Minas Gerais and Espírito Santo states. Linhares, where the river Doce flows out to the Atlantic Ocean, was the last municipality affected by the mud. The Ipiranga river, located between Linhare and São Mateus, was one of the last sites affected by the waste from the Doce river basin, having contact with the sea at the Urussuquara-ES restinga, a place that is a nursery site for biodiversity, especially marine and estuarine ichthyofauna, besides being of great importance for artisanal fishing and ecotourism. The present study aimed at monitoring the Ipiranga River and Urussuquara Beach for all seasons, from September 2017 to May 2018. The following variables were analyzed: dissolved oxygen, electrical conductivity, hydrogenation potential, transparency, temperature, depth, and total dissolved solids. The results were compared to Resolution $\mathrm{n}^{\circ}$. 357 of the Environment National Council (CONAMA), to evaluate the quality of estuarine and marine waters. The results found were alarming and evidenced a focus of negative impacts on the aquatic ecosystem and the communities that depend on artisanal fishing in these areas for their subsistence.

Keywords: Ecotoxicity, Environmental Impact, Samarco, Environmental Sanitation.

\section{Monitoramento físico-químico do ecossistema aquático de Linhares (ES) e São Mateus (ES) após o rompimento da Barragem do Fundão, Mariana, Minas Gerais}

\begin{abstract}
No dia 5 de novembro de 2015 ocorreu o rompimento da barragem de Fundão da mineradora Samarco, localizada no subdistrito de Bento Rodrigues-MG, a 35 km do centro do município brasileiro de Mariana-MG, aproximadamente 16.000 piscinas olímpicas de resíduo de mineração percolaram pelo distrito de Bento Rodrigues num período de apenas 11 minutos. A pluma deste impacto ambiental, se estendeu aproximadamente por $800 \mathrm{~km}$ na bacia do Rio Doce, entre Minas Gerais e Espírito Santo. O rio Ipiranga localizado entre Linhares e São Mateus, foi um dos últimos locais atingidos pelos resíduos da bacia do rio Doce, tendo contato com o mar na restinga de Urussuquara-ES, local que é berçário da biodiversidade, especialmente da ictiofauna marinha, e estuarina, além de ter grande importância para a pesca artesanal e o ecoturismo. O presente estudo teve como objetivo o monitoramento do rio Ipiranga e da praia de Urussuquara para todas as sazonalidades estacionais, iniciando em setembro de 2017 e tendo seu término em maio de 2018, foram analisadas as variáveis: oxigênio dissolvido, condutividade elétrica, potencial hidrogeniônico (pH), transparência, temperatura, profundidade e total de sólidos dissolvidos, comparando-as a Resolução No 357/2005 do Conselho Nacional do Meio Ambiente (CONAMA), com a finalidade de avaliar a qualidade das águas estuarinas e marinhas. Os resultados encontrados foram alarmantes e evidentes os focos de impactos negativos no ecossistema aquático e na sociedade dependente da pesca artesanal para a sua subsistência.
\end{abstract}

Palavras-chave: Ecotoxicidade, Impacto Ambiental, Samarco, Saneamento Ambiental.

Topic: Uso de Recursos Naturais

Reviewed anonymously in the process of blind peer.

Cleber Vinicius Vitorio Silva (id

Fundação Oswaldo Cruz, Brasil

http://lattes.cnpq.br/4275890458575782

http://orcid.org/0000-0001-8337-9615

clebervitorio88@gmail.com

Josimar Ribeiro de Almeida (1D)

Universidade do Estado do Rio de Janeiro, Brasil

http://lattes.cnpq.br/3215586187698472

http://orcid.org/0000-0001-5993-0665

almeida@poli.ufri.br

Carlos Eduardo Silva (iD

Universidade Tiradentes, Brasil

http://lattes.cnpq.br/3700554054159220

http://orcid.org/0000-0001-8358-0263

carlos.eduardo@cbpciencia.com.br
Received: 15/04/2018

Approved: 12/06/2018

Lyanna Oliveira de Carvalho (iD)

Centro Universitário Estadual da Zona Oeste, Brasil

http://lattes.cnpq.br/1472384194462135

http://orcid.org/0000-0003-0372-5114

yannacarvalhoadaptada@gmail.com

Carlos Domingos da Silva

Universidade Federal Rural do Rio de Janeiro, Brasil

http://lattes.cnpq.br/6460426372841261

http://orcid.org/0000-0001-8976-3220

cdambiental@gmail.com
Referencing this:

SILVA, C. V. V.; ALMEIDA, J. R.; SILVA, C. E.; CARVALHO, L. O.; SILVA, C. $D$.. Physical-chemical monitoring of the Linhares (ES) and São Mateus

(ES) aquatic ecosystem after the breaking of the Fundão Dam, Mariana, Minas Gerais. Revista Ibero Americana de Ciências Ambientais, v.9, n.5, p.1-11, 2018. DOI:

http://doi.org/10.6008/CBPC2179-6858.2018.005.0001 


\section{INTRODUCTION}

In a continuous and uninterrupted rhythm, the civilization has used water bodies for survival, with almost no management. The levels of xenobiotic compounds dumped in aquatic ecosystems, the destruction of riparian forests, and the increase of silting on the riverbanks and other water bodies have increased alarmingly as a result of the anthropogenic activity on the environment. Such fact hascontributed to the generation of environmental imbalances, affecting aquatic ecosystems beyond the levelsof stability, elasticity, and resilience. Human populations that depend on aquatic ecosystems are also affected.

The Espírito Santo state, a region with over 400 years of occupation, went through several economic cycles of exploration and production, in which its original ecosystems were gradually eliminated and, hence, not well characterized (SILVA et al., 2018). The lowland forests, restingas, mangroves, and wetlands were the ecosystems associated with the Atlantic Forest Biome that suffered the most losses and degradations from this process of occupation. Nowadays, these ecosystems are restricted to small to medium fragments, negatively impacted over a long history of agriculture, urban sprawl, and real estate projects (SIMONELLI et al., 2008). Consequently, several species of flora and fauna, characteristical of these environments, are listed in the Threatened Flora List of the state of Espírito Santo, as well as in the national (MMA) and international (IUCN) lists, being classified in different categories of threat or even considered extinct.

In the municipalities of São Mateus and Linhares, located in the mesoregion of north Capixaba coast (IBGE, 2017), the restinga prevailed, but almost the entire Atlantic Forest area was replaced by eucalyptus monoculture, livestock, and other crops as coffee, coconut, and black pepper. These cities have privileged locations for tourism and seaport activities (CARVALHO et al., 2018).

On November 5, 2015, in Bento Rodrigues, a subdistrict $35 \mathrm{~km}$ away from Mariana city, Minas Gerais state, the Fundão dam disaster took place, spreading approximately 16.000 Olympic pools of mining waste over the district of BentoRodrigues in only 11 minutes. This plume of environmental impact extended approximately $800 \mathrm{~km}$ in the River Doce basin between Minas Gerais and Espírito Santo states. Linhares, where the river Doce flows out to the Atlantic Ocean, was the last municipality affected by the mud. This region is surrounded by 69 small rivers and lakes, 27 of which are located in the municipality's headquarters, 28 in Regência, 01 in Portal do Ipiranga, 10 in São Rafael, and 03 in Desengano, according to Linhare's town hall website (CARVALHO et al., 2018).

In January 2016 a significant loss of aquatic biota, especially among ichthyofauna and carcinofauna, was recorded in the regions of Urussuquara and Barra Seca, located between Linhares and São Mateus. It was due to an extemporaneous south wind that brought the first mass of particles from the mud of Mariana, being necessary the interdiction of the beach of Pontal do Ipiranga. The Ipiranga River, located in the Urussuquara region, which further north of the state of Espírito Santo becomes the Barra Seca river, 
presented large fish mortality from January 2016 until the present time of this scientific work, having a great impact on the local economy, with a threshold of 19 months after the arrival of the mass of particulatesfrom the mud, that is, in June 2017 (CARVALHO et al., 2018).

To guarantee the quality of water supplies, several analytical techniques have been developed since the 1970 s to monitor xenobiotic compounds. More recently, a new trend emerged in the way these techniques are used, with a focus on the evaluation of the quality of the environmental compartments, to assess and mitigate the environmental impact on ecosystems. This approach is called Green Chemistry, or clean chemistry, or even self-sustaining chemistry (SILVA et al., 2016). The conceptof green chemistry includes twelve basic principles and is defined as the project, the development, and application of chemical processes aimed at the reduction, elimination, or even use of substances harmful to human health and the environment. Thus, several investigations were started to develop environmentally safe methods.

Contamination of ground and surface water resources in recent decades poses a threat to publichealth (HIRATA et al., 2010). Considering environmental contaminants, the analysis of water physicochemical characteristics constitutes an important tool for environmental quality analysis. The related parameters can be used as indicators of theecological behavior of the faunistic, floristic, and microbiological communities in aquatic ecosystems. Thus, monitoring water physicochemical parameters is of fundamental importance in assessing environmental impacts, natural or anthropogenic.

The present study aimed at monitoring all seasons, starting in September 2017 and ending in May 2018 in the waters of the Ipiranga River and the Urussuquara coast, both affected by the impacts of the Fundão dam failure in Mariana city. The following parameters were monitored: Dissolved oxygen (OD mg/L), Electric conductivity $(\mu \mathrm{S} / \mathrm{cm})$, hydrogen potential $(\mathrm{pH})$, transparency, temperature, depth, and total dissolved solids (TDS). The results were compared with Resolution N ${ }^{\circ} 357 / 2005$ of the Environment National Council (CONAMA), to evaluate the magnitude of negative environmental impacts on the regional aquatic ecosystem, as well as on the regional fishing economy that was severely affected.

\section{MATERIAL AND METHODS}

\section{Characterization of the study area}

The climates of São Mateus and Linhares are characterized, according to the Brazilian Institute of Geography and Statistics, as super humid hot tropical (Aw apud Köppen), with an average annual temperatureof $24^{\circ} \mathrm{C}$, dry and mild winters, and rainy summers with high temperatures. The hottest month, February, varies from $22^{\circ} \mathrm{C}$ to $32^{\circ} \mathrm{C}$ around an average temperature of $27^{\circ} \mathrm{C}$, while the coldest months, June and July, from $17^{\circ}$ to $27^{\circ} \mathrm{C}$ around the mean of $22^{\circ} \mathrm{C}$. 
Autumn and spring are transition seasons. The annual rainfall is approximately $1055 \mathrm{~mm}$, November being the month of greatest precipitation. The predominant soil type in the municipality is the ferralsol, with medium to low fertility, and with $\mathrm{pH}$ around 5.0, being formed from sedimentary tablelands, argillites, and sandstones. However, in the study area, the soil issandy and saline, characteristic of restinga areas (SILVA et al., 2018).

\section{Sample Design and Analysis}

The determination of the sample size is a factor of extreme importance when it comes to studies related to environmental impacts since we intend to use a more representative sample of the sample area.

The Ipiranga River and the coast of Urussuquarabeach were surveyed for fresh and marine water samples respectively. Six samples were collected randomly at each area, covering the entire sub-basin of the Ipiranga River and the entire coast of the Urussuquara beach as shown in Figure 1.

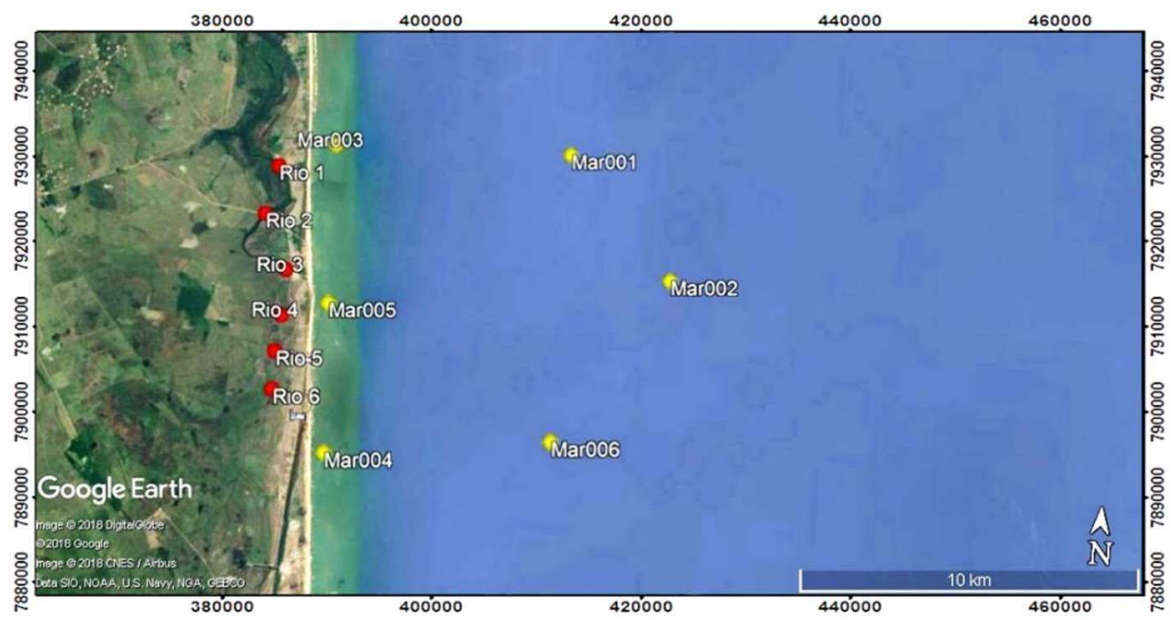

Figure 1: Sampling points along the Ipiranga River (red) and Urussuquara beach coast (yellow)

The INS-87 multiparameter probe was used to survey the abiotic parameters: Dissolved oxygen (OD $\mathrm{mg} / \mathrm{L})$, Electric conductivity $(\mu \mathrm{S} / \mathrm{cm})$, hydrogen potential $(\mathrm{pH})$, transparency, temperature, depth, and total dissolved solids (TDS), in direct comparison with the Resolution $N^{\circ} 357 / 2005$ of the Environment National Council (CONAMA). The Secchi disk was used for transparency evaluation and a bathymetric survey was performed with a Hawkeye echo sounder. Each point was georeferenced with the GPS Garmin Map 64.

The water's electrical conductivity indicates its ability to transmit electric current as a function of the dissolved substances present in it, which dissociate into anions and cations. The higher the ionic concentration of the solution, the greater the opportunity for electrolytic action and, therefore, the greater the capacity to conduct electric current (FUNASA, 2014). It also can express the interference to the passage of lightthrough the liquid, therefore, in a simplified way, it can be used to measures the transparency of the water (ANA, 2006). 
The term $\mathrm{pH}$ represents the inverse of the concentration of hydrogen ions in a solution, which can be determined by devices called potentiometers or colorimeters (PALUDO, 2010). According to FELTRE (2004), $\mathrm{pH}$ indicates whether the medium is acidic $(\mathrm{pH}<7)$, alkaline $(\mathrm{pH}>7)$, or neutral $(\mathrm{pH}=7)$. Each medium has its $\mathrm{pH}$ value. The normal $\mathrm{pH}$ of marine waters ranges from 6.5 to 8.5 .

Electrical conductivity refers to the ability of water to transmit electrical current due to ions, either cations (positive charges) or anions (negative charges), present in it due to the dissociation of other substances (ANA,2006).

Total dissolved solids are the set of all organic and inorganic substances contained in a liquid in ionized or microgranular molecular forms (ARAÚJO et al. 2016). The entry of solids into the water can occur naturally (erosive processes, organisms, and organic debris) or anthropogenically, as waste disposal, sewage, and illegal mining among others (OGA et al., 2014).

The transparency of the water measured by the Secchi disk varies greatly between aquatic ecosystems and can vary throughout the day in a given location, depending on the circulation regime of the water body, the geochemical nature of the basin, and the rainfall regime (BARRETO, 2010). Despite the relationship between dissolved organic matter and water transparency, as measured by the Secchi disc, it has been demonstrated that the reduction of light transmission is strongly related to the increase in dispersion due to suspended particulate matter. Hence, in veryproductive lakes this parameter has also been used to infer phytoplankton density, and to evaluate the density of particulates in water from anthropogenic activities such as mining waste (GOMES, 2005). According to the Secchi disc depth, a lake can be classified as oligotrophic (greater than or equal to $4.6 \mathrm{~m}$ ), oligotrophic-mesotrophic (between $4.5-3.8 \mathrm{~m}$ ), mesotrophic (between 3.7 and $2.4 \mathrm{~m}$ ), mesotrophic-eutrophic (between 2.3 and $1.8 \mathrm{~m}$ ), and eutrophic (less than or equal to $1.7 \mathrm{~m}$ ). Thus, pronounced changes inthe seasonal pattern of water transparency can serve as a warning signal to local authorities and NGOs for the establishment of proposals and actions for the recovery of a given waterbody. Periodic measurements ofthe Secchi disk and at various points of a lake are advisable. In this way, it will be possible to establish a satisfactory spatial and temporal analysis of the studied system (FUNASA, 2014).

Dissolved oxygen is the concentration of oxygen $\left(\mathrm{O}_{2}\right)$ contained in water, being essential for all forms of aquatic life. Aquatic systems produce and consume oxygen, which is withdrawn from the atmosphere at the water-air interface and is also obtained as a result of the photosynthetic activities of algae and plants. The amount of oxygen present in the water under normal conditions depends on temperature, the concentration of salts, and atmospheric pressure. The solubility of gases in water decreases with temperature and increases with salinity. The determination of dissolved oxygen concentration is of fundamental importance in the evaluation of water quality since oxygen is involved in practically all chemical and biological processes. Excessive release of organic material into the water, or residues that prevent light fromentering the aquatic system, can result in oxygen depletion. Prolonged exposure at concentrations below $5 \mathrm{mg} / \mathrm{L}$ may not kill some organisms, but increase susceptibility to stress. 
Exposure below $2 \mathrm{mg} / \mathrm{L}$ can lead to the death of most organisms (SCALIZE, 2014). The field surveys were carried out in all seasons of the year, as shown in Table 1.

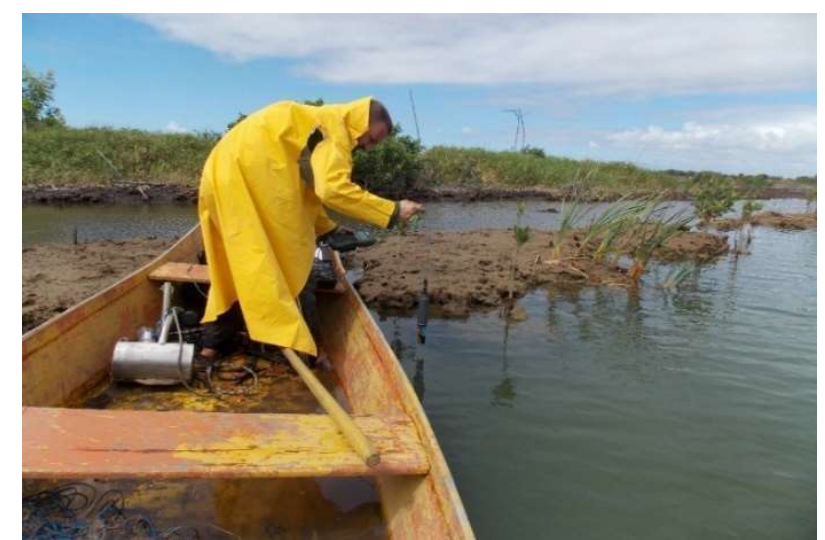

Figure 2: Data collection with the multiparametric probe in the Ipiranga River, at the sampling area RIO 4 (423093.00 $\mathrm{m}$ E7890925.00 m S).

Table 1: Seasonality and collection dates.

\begin{tabular}{|c|c|}
\hline Seasonal & Collection date \\
\hline winter & $31 / 08 / 2017$ to $02 / 09 / 2017$ \\
\hline spring & $30 / 11 / 2017$ to $03 / 12 / 2017$ \\
\hline summer & $03 / 02 / 2018$ to $07 / 02 / 2018$ \\
\hline autumn & $27 / 05 / 2018$ to $30 / 05 / 2018$ \\
\hline
\end{tabular}

All parameters were statistically described in terms of mean, standard deviation, variance, standard error, and coefficient of variation, in all seasons. The multivariate analysis aims to reduce many variables in a few dimensions with the minimum loss of information, allowing the detection of the main patterns of similarity and association between the sample units. To understand the similarity between sampling points and seasons, cluster analysis was used according to the sample environment based on the similarity matrix and the Bray-Curtis index(ZAR, 1999). The Bray-Curtis index ranges from 0 to 1, with lower values indicating more similar samples. This standardization in the interval between one and zero facilitates interpretation and comparison. The resultingvalues between pairs of station samples were arranged in a similarity matrix. This similarity matrix was subjected to clustering analysis, using the single bond as the binding method. The statistical analysis was performed with the aid of the software Past developed by Taguchi et al. (2005), and Microsoft Excel 2010.

All the results collected were compared to Resolution $N^{\circ} 357 / 2005$ of the Environment National Council (CONAMA), to evaluate the environmental quality of the estuary and the marineenvironment, following the environmental disaster of the rupture of the Fundão dam.

\section{RESULTS AND DISCUSSIONS}

The univariate statistical analysis showed that for all variables reliable results were obtained for all seasons and sample environments (Table 2). 
Table 2: Univariate parameters of the abiotic variables collected in the seasons of the year for the marine and estuarine ecosystem of Urussuquara-ES. In red are all the variables that do not conform to Resolution $\mathrm{N}^{\circ} 357 / 2005$ of the Environment National Council (CONAMA).

\begin{tabular}{|c|c|c|c|c|c|c|c|}
\hline \multicolumn{8}{|c|}{ Winter 2017} \\
\hline Estuarine Ecosystem & pH & ${ }^{\circ} \mathrm{C}$ & Conductivity $(\mu \mathrm{S} / \mathrm{cm})$ & TDS (ppm) & OD (mg/L) & Secchi disk (m) & Total Depth (m) \\
\hline$\overline{\mathbf{x}}$ & 7.02 & 22.80 & 1039.17 & 518.67 & 4.83 & 0.62 & 1.27 \\
\hline$S$ & 0.23 & 0.38 & 37.35 & 20.03 & 1.23 & 0.10 & 0.80 \\
\hline$S^{2}$ & 0.05 & 0.15 & 1394.97 & 401.07 & 1.52 & 0.01 & 0.65 \\
\hline Sx & 0.09 & 0.16 & 15.25 & 8.18 & 0.50 & 0.04 & 0.33 \\
\hline cv\% & 3.24 & 1.68 & 3.59 & 3.86 & 25.58 & 15.94 & 63.49 \\
\hline Marine Ecosystem & $\mathrm{pH}$ & ${ }^{\circ} \mathrm{C}$ & Conductivity $(\mu \mathrm{S} / \mathrm{cm})$ & TDS (ppm) & OD (mg/L) & Secchi disk (m) & Total Depth (m) \\
\hline$\overline{\mathbf{x}}$ & 8.46 & 23.18 & 962.67 & 507.67 & 41.97 & 4.28 & 11.67 \\
\hline $\mathbf{S}$ & 0.20 & 0.08 & 14.53 & 40.37 & 1.48 & 0.35 & 7.28 \\
\hline$S^{2}$ & 0.04 & 0.01 & 211.07 & 1629.87 & 2.19 & 0.12 & 53.07 \\
\hline Sx & 0.08 & 0.03 & 5.93 & 16.48 & 0.60 & 0.14 & 2.97 \\
\hline cv\% & 2.34 & 0.34 & 1.51 & 7.95 & 3.53 & 8.14 & 62.44 \\
\hline \multicolumn{8}{|c|}{ Spring 2017} \\
\hline Estuarine Ecosystem & pH & ${ }^{\circ} \mathrm{C}$ & Conductivity $(\mu \mathrm{S} / \mathrm{cm})$ & TDS (ppm) & OD (mg/L) & Secchi disk (m) & Total Depth (m) \\
\hline$\overline{\mathbf{x}}$ & 7.49 & 25.92 & 29.96 & 15.10 & 1.51 & 0.50 & 2.35 \\
\hline $\mathbf{S}$ & 0.25 & 0.19 & 1.91 & 0.79 & 1.54 & 0.00 & 1.12 \\
\hline$S^{2}$ & 0.06 & 0.04 & 3.66 & 0.62 & 2.38 & 0.00 & 1.25 \\
\hline Sx & 0.10 & 0.08 & 0.78 & 0.32 & 0.63 & 0.00 & 0.46 \\
\hline cv\% & 3.39 & 0.75 & 6.38 & 5.22 & 102.13 & 0.00 & 47.52 \\
\hline Marine Ecosystem & $\mathrm{pH}$ & ${ }^{\circ} \mathrm{C}$ & Conductivity $(\mu \mathrm{S} / \mathrm{cm})$ & TDS (ppm) & $O D(\mathrm{mg} / \mathrm{L})$ & Secchi disk (m) & Total Depth (m) \\
\hline$\overline{\mathbf{x}}$ & 8.42 & 26.50 & 36.80 & 18.61 & 15.59 & 3.67 & 10.83 \\
\hline$S$ & 0.15 & 0.13 & 5.58 & 1.52 & 5.56 & 3.87 & 6.05 \\
\hline$S^{2}$ & 0.02 & 0.02 & 31.10 & 2.31 & 30.96 & 14.97 & 36.57 \\
\hline Sx & 0.06 & 0.05 & 2.28 & 0.62 & 2.27 & 1.58 & 2.47 \\
\hline cv\% & 1.78 & 0.48 & 15.15 & 8.17 & 35.70 & 105.51 & 55.82 \\
\hline \multicolumn{8}{|c|}{ Summer 2018} \\
\hline Estuarine Ecosystem & $\mathrm{pH}$ & ${ }^{\circ} \mathrm{C}$ & Conductivity $(\mu \mathrm{S} / \mathrm{cm})$ & TDS (ppm) & OD (mg/L) & Secchi disk (m) & Total Depth (m) \\
\hline$\overline{\mathbf{x}}$ & 7.24 & 25.96 & 34.26 & 17.32 & 4.10 & 0.38 & 2.42 \\
\hline $\mathbf{S}$ & 0.33 & 0.61 & 4.16 & 2.48 & 1.26 & 0.13 & 1.23 \\
\hline$S^{2}$ & 0.11 & 0.38 & 17.35 & 6.16 & 1.58 & 0.02 & 1.51 \\
\hline Sx & 0.14 & 0.25 & 1.70 & 1.01 & 0.51 & 0.05 & 0.50 \\
\hline cv\% & 4.57 & 2.37 & 12.16 & 14.34 & 30.67 & 34.67 & 50.77 \\
\hline Marine Ecosystem & $\mathrm{pH}$ & ${ }^{\circ} \mathrm{C}$ & Conductivity $(\mu \mathrm{S} / \mathrm{cm})$ & TDS (ppm) & $O D(\mathrm{mg} / \mathrm{L})$ & Secchi disk (m) & Total Depth (m) \\
\hline$\overline{\mathbf{x}}$ & 8.43 & 26.87 & 48.45 & 27.75 & 19.61 & 3.67 & 12.42 \\
\hline$S$ & 0.16 & 0.15 & 1.63 & 1.24 & 4.31 & 4.19 & 6.40 \\
\hline$S^{2}$ & 0.02 & 0.02 & 2.66 & 1.53 & 18.58 & 17.58 & 40.94 \\
\hline Sx & 0.06 & 0.06 & 0.67 & 0.51 & 1.76 & 1.71 & 2.61 \\
\hline cv\% & 1.86 & 0.57 & 3.37 & 4.46 & 21.98 & 114.35 & 51.53 \\
\hline \multicolumn{8}{|c|}{ Autumn 2018} \\
\hline Estuarine Ecosystem & $\mathrm{pH}$ & ${ }^{\circ} \mathrm{C}$ & Conductivity $(\mu \mathrm{S} / \mathrm{cm})$ & TDS (ppm) & OD (mg/L) & Secchi disk (m) & Total Depth (m) \\
\hline$\overline{\mathbf{x}}$ & 7.47 & 24.33 & 31.24 & 21.17 & 4.05 & 0.38 & 2.42 \\
\hline$S$ & 0.55 & 0.52 & 8.41 & 5.28 & 0.07 & 0.13 & 1.23 \\
\hline$S^{2}$ & 0.30 & 0.27 & 70.65 & 27.87 & 0.01 & 0.02 & 1.51 \\
\hline Sx & 0.22 & 0.21 & 3.43 & 2.16 & 0.03 & 0.05 & 0.50 \\
\hline cv\% & 7.34 & 2.12 & 26.91 & 24.93 & 1.81 & 34.67 & 50.77 \\
\hline Marine Ecosystem & $\mathrm{pH}$ & ${ }^{\circ} \mathrm{C}$ & Conductivity $(\mu \mathrm{S} / \mathrm{cm})$ & TDS (ppm) & OD (mg/L) & Secchi disk (m) & Total Depth (m) \\
\hline$\overline{\mathbf{x}}$ & 8.53 & 25.00 & 50.92 & 28.47 & 25.26 & 1.67 & 12.42 \\
\hline $\mathbf{S}$ & 0.24 & 0.00 & 1.42 & 0.95 & 6.10 & 1.44 & 6.40 \\
\hline$S^{2}$ & 0.06 & 0.00 & 2.01 & 0.90 & 37.21 & 2.07 & 40.94 \\
\hline Sx & 0.10 & 0.00 & 0.58 & 0.39 & 2.49 & 0.59 & 2.61 \\
\hline cv\% & 2.79 & 0.00 & 2.79 & 3.34 & 24.15 & 86.26 & 51.53 \\
\hline
\end{tabular}

Source: collected in the field with the INS-87 multiparametric probe.

The estuarine ecosystem presented concentrations of dissolved oxygen below that regulated in Resolution $N^{\circ} 357 / 2005$ of the Environment National Council (CONAMA), with an average concentration of $1.51(\mathrm{mg} / \mathrm{L})$ for the spring of 2017. 
According to CENTRO TAMAR (2016), there was significant mortality of aquatic organisms in the Ipiranga River, in the second half of 2016 and the first half of 2017, a fact that may be correlated with the rupture of the Fundão dam. The solids act indirectly on aquatic life, prevent the penetration of light, induce the heating of the water which, consequently, decreases the amount of oxygen dissolved in the medium (LOUGON, 2009). According to the CENTRO TAMAR (2016), there were large concentrations of iron in the mining tailings that percolated the River Doce basin. Waters rich in $\mathrm{Fe}^{+3}$ ions may show an increase in their turbidity when they encounter oxygen in the air (CORCÓVIA, 2012). Immediate contact of the iron ion (Fe) with the tropospheric oxygen $\left(\mathrm{O}_{2}\right)$ occurs in a chemical reaction and the iron ion becomes iron oxide $\left(\mathrm{Fe}_{2} \mathrm{O}_{3}\right)$, also called rust, which substance is responsible for the color browning of rusted materials. In September 2017 concentrations of total solids above 500 ppm were registered, being out of compliance with Resolution $\mathrm{N}^{\circ}$ $357 / 2005$ of the Environment National Council (CONAMA). This event is probably anthropogenic, since no random or stochastic natural events were reported, capable of maximizing both the concentration of total dissolved solids in the waters of the Ipiranga River and the coast of Urussuquara.

Normally, the electrical conductivity of natural waters is less than $500 \mu \mathrm{S} / \mathrm{cm}$, and higher values may indicate pollution problems (ANA, 2006). Values higher than $1000 \mu \mathrm{S} / \mathrm{cm}$ were found for the estuarine and marine ecosystems, and the Ipiranga River presented a concentrationof dissolved salts higher than the one found at Urussuquara beach, probably as a result of the Fundão dam disaster.

Although salt concentrations stabilized from the spring of 2017 onwards, low concentrations of dissolved oxygen persisted, probably due to changes in the color of water, as indicated by the Secchi disk results, that presented averages below $0.65 \mathrm{~m}$ in all seasons. This situation is similar to those common in eutrophic environments. However, as explained above, the process of water darkening that took place at the studied estuary followed a distinct pattern, differing from the classical process of eutrophication due to the high concentration of nutrients. In the Ipiranga River, this process could be explained by the high concentration of dissolved salts, especially iron. It is possible thatsome material from the Fundão dam was deposited in the bottom of the drainage, thus still influencing the color dynamics, and consequently that of dissolved oxygen, of the Ipiranga River.

The only parameter found in the marine environment to be altered was the $\mathrm{pH}$ during the autumn of 2018. Resolution $N^{\circ} 357 / 2005$ of the Environment National Council (CONAMA) establishes a limit of 8.5 for pH in marine waters, while the measured $\mathrm{pH}$ was 8.53 .

The clustering analysis of the Bray-Curtis similarity between estuarine and marine sample areas for all seasons resulted in the graphs shown in Figures 3 and 4. For the analysis of structured groups, the level of $80 \%$ of the highest relative similarity between the terminals was considered. The cluster analysis presented two groups at the $80 \%$ level of similarity, denominated A and B. These groups were differentiatedby the monitored parameters for the different areas and seasons. 
Group A was represented by all seasons and sample areas, except for winter. For group B, all sampled areas during winter showed similarities. It is justified that during the winterof 2017 the concentration of total dissolved solids $(\mathrm{ppm})$ and the conductivity $(\mu \mathrm{S} / \mathrm{cm})$ were about 30 times higher than the concentrations found in the other seasons, as mentioned previously, probably due to the mining tailings from the Fundão dam failure, that percolated to the estuarine region of Urussuquara.

For the marine ecosystem, groups A and B presented forms similar to the estuarine ecosystem, where group A represented all seasonal and sampled areas, except for winter, and group B was composedof all sample areas, but only for the winter season. For the marine ecosystem, the concentration of total dissolved solids (ppm) and the conductivity $(\mu \mathrm{S} / \mathrm{cm})$ were also about 30 times higher than the concentrations found in other seasons.

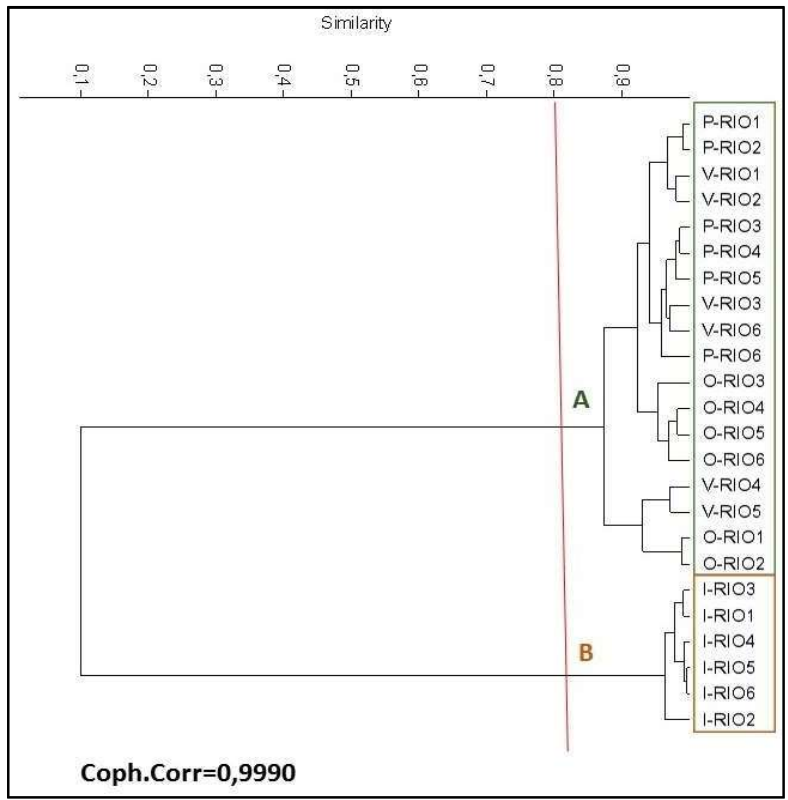

Figure 3: Result of the cluster analysis between the sampled areas for all the seasons of the estuarine ecosystem. Cut at the $80 \%$ level of similarity. Caption: Iwinter; P-spring; V- summer and O-autumn.

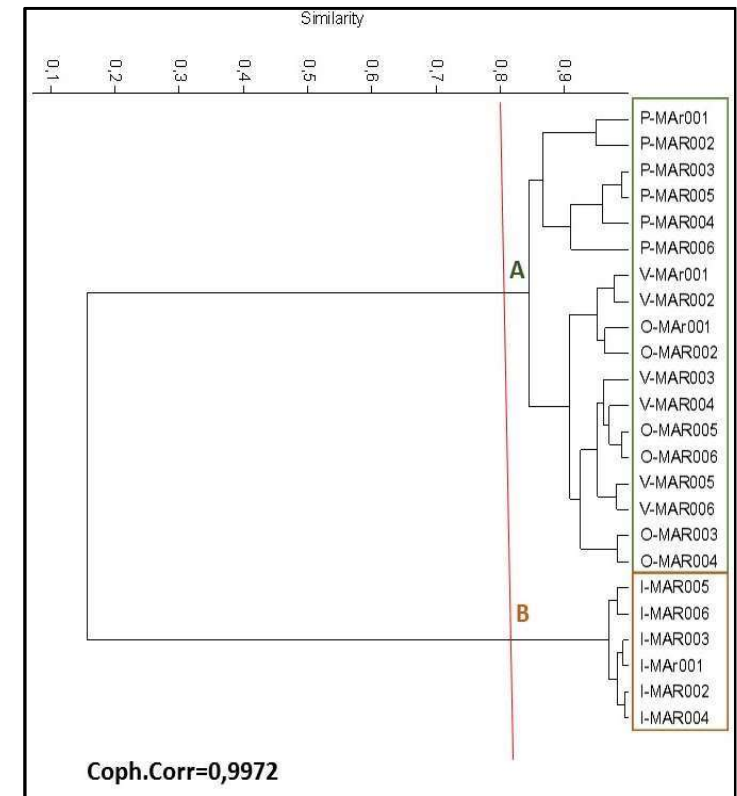

Figure 4: Result of the cluster analysis between the sampled areas for all the seasons of the marine ecosystem. Cut at the $80 \%$ level of similarity. Caption: Iwinter; P-spring; V- summer and O-autumn.

\section{CONCLUSIONS}

The municipality of Linhares-ES, located about $800 \mathrm{~km}$ from the Fundão dam failure site, was the last legal district to be impacted by its mining tailings. The water physical-chemical quality database generated by the monitoring of the estuarine and marine ecosystems of Urussuquara-ES, indicates that some parameters were above the limits prescribed by Resolution $N^{\circ} 357 / 2005$ of the Environment National Council (CONAMA). Dissolved oxygen for the estuarine ecosystem in all seasons; total dissolved solids and conductivityfor both the estuarine and marine ecosystems during the winter of 2017; and pH for themarine ecosystem during the summer of 2018 were all above the prescribed limits, representing a threat to the human population that uses these ecosystems, as well as the aquatic biota, thus justifying the significant fish mortality found in the Ipiranga River in the second half of 2016 and the first half of 2017. 
Given that the outlet of the Ipiranga River may have continued to link the Fundão dam disaster to the sea even in 2018, and due to the dynamics of the marine and estuarine environments, it is necessary that the monitoring of the plume and the assessment of its impacts continue to be carried out in the following years, including the water physical-chemical monitoring of the Ipiranga River and the Urussuquara Beach Coast.

Further, actions are needed that focus on environmental education and the remediation of these ecosystems, as well as the participation of public authorities, municipalities, research institutes, universities, and NGOs, focusing on human, animal welfare, and environmental sustainability in a holistic way, given the importance of the Ipiranga River and the coast of Urussuquara beach for artisanal fishing, as well as the ecological importance of the estuary to aquatic ecosystems, as they provide food and shelter through a range of habitats and microhabitats, being of paramount importance to the benthic guild, essential organisms in the structure of the aquatic trophic chain, as well as nursery of several fish species, in addition to crustaceans and mollusks that depend on these environments to complete their story of life.

\section{REFERENCES}

ANA. Agência Nacional de Águas. Ministério do Meio Ambiente. Plano Estratégico de Recursos Hídricos das Bacias Hidrográficas dos Rios Guandu, da Guarda e Guandu Mirim: Relatório do Diagnóstico Final. Brasília: ANA, 2006.

ARAUJO, M. C.; OLIVEIRA, M. B. M.. Monitoramento da qualidade das águas de um riacho da Universidade Federal de Pernambuco, Brasil. Rev. Ambient. Água, v.8, n.3, p.247257, 2013. DOI: http://dx.doi.org/10.4136/ambi-agua.1192

BARRETO, P. R.; GARCIA, C. A. B.. Caracterização da qualidade da água do açude Buri, Frei Paulo/SE. Scientia Plena, v.6, n.9, p.1-21, 2010.

BAIRD, C.. Química Ambiental. Porto Alegre: Bookman, 2002.

BRASIL. Ministério do Meio Ambiente. Conselho Nacional do Meio Ambiente. Resolução CONAMA n.357, de 17 de março de 2005. Dispõe sobre a classificação dos corpos de água e diretrizes ambientais para o seu enquadramento, bem como estabelece as condições e padrões de lançamento de efluentes, e dá outras providências. Brasília: DOU, 2005.

BRASIL. Ministério do Meio Ambiente. Conselho Nacional do Meio Ambiente. Resolução № 420, de $\mathbf{2 8}$ de dezembro de 2009. Dispõe sobre critérios e valores orientadores de qualidade do solo quanto à presença de substâncias químicas e estabelece diretrizes para o gerenciamento ambiental de áreas contaminadas por essas substâncias em decorrência de atividades antrópicas. Brasília: DOU, 2009.

CARVALHO, L. O.; SILVA, C. V. V.; TOMAS JUNIOR, O. A.; ESPER, F. J.. O Uso do Tanque de Aquicultura Como Proposta de Resgate da Ictiofauna Após o Desastre Ambiental de Mariana-MG. In: SEMANA ACADÊMICA DE BIOLOGIA DA UFRRJ, 38. Anais. Seropédica: UFRRJ, 2018.

CENTRO TAMAR; ICMBIO. Nota Técnica 010/2016:

Informações para resposta ao Requerimento de Informação no 1515/2016, da Comissão Externa do Rompimento de Barragem na região de Mariana-MG. 2016a.
CENTRO TAMAR; ICMBIO. Nota Técnica 001/2016: Análise da proibição de pesca de camarão e demais recursos pesqueiros na região marinha próxima à foz do rio Doce (Aracruz e Linhares/ES). 2016b.

CORCÓVIA, J. A.; CELLIGOI, A.. Avaliação preliminar da qualidade da água subterrânea no município de Ibiporã-PR. Revista de Estudos Ambientais, v.14, n.2, p.39-48, 2012. DOI: http://doi.org/10.7867/1983-1501.2012v14n2p39-48

FELTRE, R.. Físico-química. 6 ed. São Paulo: Moderna, 2004.

FUNASA. Fundação Nacional De Saúde. Manual de Controle da Qualidade da Água para Técnicos que Trabalham em ETAS. Brasília: FUNASA, 2014.

GOMES, A. S.; CLAVICO, E.. Propriedades físico-químicas da água. Rio de Janeiro: UFF (Departamento de Biologia Marinha), 2005.

HIRATA, R.; ZOBBI, J.; OLIVEIRA, F.. Águas subterrâneas: reserva estratégica ou emergencial. In: BICUDO, C.; TUNDISI, J; SCHEUENSTUHL, M.. Águas do Brasil: análises estratégicas. São Paulo: Instituto de Botânica, 2010. p.144-164

IBGE. Instituto Brasileiro de Geografia e Estatística. Censo Agropecuário 2017. Rio de Janeiro: IBGE, 2017.

OGA, S.; CAMARGO, M. M. A.; BATISTUZZO, J. A. O.. Fundamentos de Toxicologia. 4 ed. São Paulo: Atheneu, 2014.

PALUDO, D.. Qualidade da Água nos poços artesianos do Município de Santa Clara do Sul. Lajeado: UNIVATES, 2010.

SCALIZE, P. S.; BARROS, E. F. S.; SOARES, L. A.; HORA, K. E. R.; FERREIRA, N. C.; BAUMANN, L. R. F.. Avaliação da qualidade da água para abastecimento no assentamento de reforma agrária Canudos, Estado de Goiás. Rev. Ambient. Água, v.9, n.4, Taubaté, 2014. DOI: http://doi.org/10.4136/ambiagua. 1386 
SILVA, C. V. V.; CARVALHO, L. O.; TOMAS JUNIOR, O. A.; ESPER, F. J.. Levantamento da Mirmecofauna da Restinga de Urussuquara-ES. In: SEMANA ACADÊMICA DE BIOLOGIA DA UFRRJ, 38. Anais. Seropédica: UFRRJ, 2018.

SILVA, C. V. V.; ABREU, L. A. S.. Biomonitoramento de Macroinvertebrados Bentônicos na Avaliação Ambiental da Represa Billings, SP. In: CONGRESSO NACIONAL DE MEIO AMBIENTE DE POÇOS DE CALDAS, 13. Anais. Poços de Caldas, 2016.

SILVA, C. V. V.; TOMAS JUNIOR, O. A.; CARVALHO, L. O.; ABREU, L. A. S.. Monitoramento de Quelônios Marinhos em
Linhares-ES Após o Desastre Ambiental de Mariana-MG. In: Congresso Nacional do Meio Ambiente, 15. Anais. Poços de Caldas, 2018.

SIMONELLI, M.; MAGNAGO, L. F. S.; FONTANA, A. P.; KOLLMANN, L. J. C.; MATOS, F. R.. Composição florística visando a subsidiar ações de conservação em Serra das Torres, Espírito Santo, Brasil. Revista Científica da FAESA v.4, p.39-46, 2008. DOI: http://doi.org/10.5008/1809.7367.016

ZAR, J. H.. Biostatistical analysis. 4 ed. New Jersey: PrenticeHall, 1999.

A CBPC - Companhia Brasileira de Produção Científica (CNPJ: 11.221.422/0001-03) detém os direitos materiais desta publicação. Os direitos referem-se à publicação do trabalho em qualquer parte do mundo, incluindo os direitos às renovações, expansões e disseminações da contribuição, bem como outros direitos subsidiários. Todos os trabalhos publicados eletronicamente poderão posteriormente ser publicados em coletâneas impressas sob coordenação da Sustenere Publishing, da Companhia Brasileira de Produção Científica e seus parceiros autorizados. Os (as) autores (as) preservam os direitos autorais, mas não têm permissão para a publicação da contribuição em outro meio, impresso ou digital, em português ou em tradução. 